\title{
The evaluation of the cases with extrapulmonary tuberculosis
}

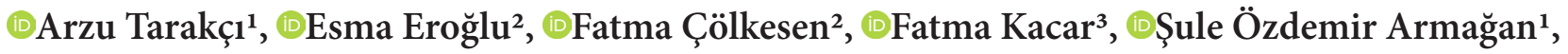 \\ (1)Selver Can ${ }^{4}$ \\ ${ }^{1}$ Konya City Hospital, Department of Infectious Diseases and Clinical Microbiology, Konya, Turkey \\ ${ }^{2}$ Konya Meram State Hospital, Department of Infectious Diseases and Clinical Microbiology, Konya, Turkey \\ ${ }^{3}$ Konya Medova Private Hospital, Clinic of Infectious Diseases and Clinical Microbiology, Konya, Turkey \\ ${ }^{4}$ Konya Beyhekim Training and Research Hospital, Department of Infectious Diseases and Clinical Microbiology, Konya, Turkey
}

Cite this article as: Tarakçı A, Eroğlu E, Çölkesen F, Kaçar F, Özdemir Ş, Can S. The evaluation of the cases with extrapulmonary tuberculosis. J Health Sci Med 2021; 4(4): 451-456.

\begin{abstract}
Objective: Tuberculosis (TB) involving all organs is a disease progressing with a wide range of clinical presentations. It is especially difficult to diagnose cases of extrapulmonary tuberculosis (EPTB) due to the a typical course. The cases of EPTB constitute approximately $35 \%$ of all TB cases in our country. In our study, it was aimed to examine the distribution rates, diagnostic methods, and treatment processes of EPTB in terms of the involved systems.

Material and Method: Of 308 patients diagnosed with TB, 119 cases having EPTB were retrospectively analyzed in The Konya Training and Research Hospital of Health Sciences University between $1^{\text {st }}$ January 2015 and $30^{\text {th }}$ June 2019.

Results: Of 308 cases diagnosed with TB, 119 (38.6\%) EPTB cases were included in the study. Sixty-three (52.9\%) and 56 (47\%) patients were women and men, respectively. The average age was found as $44.42 \pm 18.8$ years (min: 18 , max: 91 years). The distribution of involvement sites of EPTB was as follows: lymphadenitis, $45.4 \%$; pleural tuberculosis, 24.4\%; peritonitis, $14.3 \%$; bone-joint tuberculosis, 7.5\%; meningitis, $2.5 \%$; miliary tuberculosis, $1.7 \%$; others, $4.2 \%$. In terms of EPTB, 83 (69.7\%) cases were diagnosed histopathologically, and 28 (23.5\%) and nine (7.5\%) had culture and acido-resistant bacilli (ARB) positivity, respectively. A total of 29 (24.3\%) cases were diagnosed microbiologically, and the purified protein derivative (PPD) positivity was detected in $106(89 \%)$ cases. While the success rate of the treatment was found to be $93.2 \%$, the mortality rate was measured as $3.3 \%$.

Conclusion: It should be kept in mind that TB is a common multisystem disease in our country and may present itself with a wide range of symptoms. In the presence of clinical suspicion, supportive tests should be performed; biopsy and culture samples should be obtained from the appropriate tissues; anti-TB treatment should be initiated at once if clinicians have sufficient evidence.
\end{abstract}

Keywords: Extrapulmonary tuberculosis, diagnosis, histopathological, microbiological

\section{INTRODUCTION}

Presenting very wide clinical findings, tuberculosis (TB) is a disease that can involve almost any organ in humans. Extrapulmonary tuberculosis (EPTB), however, is witnessed in approximately $35 \%$ of allcases in Turkey (1). Although TB can involve all tissues and organs, the types and main involvement sites of EPTB are lymphadenitis, miliary TB, central nervous system (CNS), bone-joint $\mathrm{TB}$, pleural and pericardial TB, and TB of genitourinary (GUS) and gastrointestinal (GIS) systems. The type of EPTB most commonly encountered in our country is pleural TB. It is difficult to diagnose the cases of EPTB, and so the diagnosis can often be ignored (2). When EPTB is suspected, and the diagnosis process is supported by clinical and laboratory findings, anti-tuberculosis treatment should be initiated at once. The fact that the treatment modalities are initiated at an earlier phase is so important to reduce morbidity and mortality (1).

The present study aims to draw attention to the cases with EPTB, which is still an important public health problem in our country, since its diagnosis can be generally ignored, delayed, or not considered due to the delays in the treatment by evaluating the cases in terms of patients' demographic characteristics, an anatomical sites of the involvements, diagnostic procedures and the outcomes of the treatment modalities. 


\section{MATERIAL AND METHOD}

An approval was obtained from the Medical Specialty Education Board of Konya Training and Research Hospital (Date: 01/08/2019, Desicion No: 28-01). All procedures were carried out in accordance with the ethical rules and the principles of the Declaration of Helsinki.

Among a total of 308 patients diagnosed with TB in The Konya Training and Research Hospital of Health Sciences University between $1^{\text {st }}$ January 2015 and $30^{\text {th }}$ June 2019, 119 cases with EPTB were included and analyzed retrospectively in our study. The patients under 18 years of age were excluded from the criteria. For the study, approval was obtained from The Medical Specialty Education Board (TUEK) of the hospital. Since the study was of a retrospective design, approval from the ethical board of an institution was considered not to be necessary. The information related to the patients was obtained by scanning the hospital automation system and analyzed retrospectively. EPTB cases were diagnosed by determining one or more of the following criteria:

1. The determination of claseified granulomatous or granulomatous necrosis in the histopathological examination on the biopsy material obtained from the current focus.

2. The demonstration of $A R B$ in the microscopic examination or culture of material obtained from the current focus.

3. The presence of the response to the anti-TB treatment administered, as well as the positivity of the PPD test, in case of clinical/radiological compatibility with EPTB.

The demographic characteristics, accompanying comorbid diseases, PPD results, histories of previous treatment regimes (case definition), foci of involvements, diagnostic methods and treatment protocols of the patients diagnosed with EPTB were recorded. The definitions of the cases were created under The 2019 National Tuberculosis Diagnosis and Treatment Guidelines (1). The diagnostic and treatment protocols were determined under the recommendations by The World Health Organization (WHO). The treatment outcomes were also defined as the cure, completion of the treatment performed, withdrawal from the treatment, therapeutic failure, and death under the criteria by WHO (3).

\section{Statistical Analysis}

The statistical analyzes were performed using the statistical software of the Statistical Package for Social Sciences (SPSS) for Windows, version 18.0 program (SPSS Inc, Chicago, IL, USA).The descriptive variables and the findings of mean \pm standard deviation (SD) were also analyzed.

\section{RESULTS}

Among 308 cases reported to have TB, 119 (38.6\%) were detected to be EPTB patients and included in the study. Of 119 patients, $63(52.9 \%)$ and $56(47 \%)$ were female and male, respectively, and the patients' average age was measured as $44.42 \pm 18.8$ years (min: 18 , max: 91 years). While $99(82.2 \%)$ of the patients were Turkish citizens, $20(16.8 \%)$ were citizens of other countries, such as Syria, Afghanistan, and Azerbaijan.

Considering the existence of predisposing comorbid diseases, the distribution of the disorders was as follows: diabetes mellitus (DM) in eight (6.7\%) patients, malignancy in six (5\%) patients, chronic renal failure (CRF) in eight (6.7\%) patients, and chronic obstructive pulmonary disease (COPD) in five (4.2\%) patients. Of 119 EPTB patients in the study, while $103(86,6 \%)$ were examined in the out-patient clinics, $16(13.4 \%)$ were treated in the in-patient units. Even so, while 111 (92.2\%) were newly diagnosed TB patients, seven (5.8\%) were detected to have recurrent $\mathrm{TB}$, and one $(0.8 \%)$ case was also seen to abandon the treatment. The distribution of EPTB is shown in Table 1, and the distribution of lymphadenitis under the involvement sites is demonstrated in Table 2.

\begin{tabular}{|lcc|}
\hline \multicolumn{3}{l}{ Table 1. The distribution of extrapulmonary tuberculosis cases } \\
under the systems & n & $\%$ \\
\hline EPTB & 54 & 45.4 \\
\hline Lymphadenitis & 29 & 24.4 \\
Pleural tuberculosis & 17 & 14.3 \\
Peritonitis & 9 & 7.5 \\
Bone-joint tuberculosis & 3 & 2.5 \\
Meningitis & 2 & 1.7 \\
Miliary tuberculosis & 2 & 1.7 \\
Laryngeal tuberculosis & 2 & 1.7 \\
Tuberculosis of GIS & 1 & 0.8 \\
Tuberculosis of GUS & 119 & 100 \\
Total &
\end{tabular}

EPTB: Extrapulmonary tuberculosis, GIS: Gastro-intestinal system, GUS: Genitourinary system

\begin{tabular}{|lcc|}
\hline \multicolumn{3}{|l|}{ Table 2. Distribution of the involvement sites of lymphadenopathies } \\
\hline Localizations of LAPs & $\mathbf{n}$ & \% \\
\hline Cervical LAP & 28 & 51.9 \\
Axillary LAP & 23 & 42.6 \\
Mediastinal LAP & 3 & 5.5 \\
Total & 54 & 100 \\
\hline LAP: Lymphadenopathy & \\
\hline
\end{tabular}

In terms of EPTB, $83(69.7 \%)$ cases were diagnosed histopathologically, $28(23.5 \%)$ and nine $(7.5 \%)$ were found to have culture and ARB positivity, respectively. On the other hand, a total of $29(24.3 \%)$ cases were diagnosed microbiologically, and the PPD positivity was detected in 106 (89\%) cases. The diagnostic methods, and the PPD positivity and mortality rates concerning the involvement sites of EPTB are presented in Table 3. 
Table 3. Diagnostic methods, and PPD positivity and mortality rates according to EPTB involvement regions

\begin{tabular}{|c|c|c|c|c|c|c|c|}
\hline \multirow{2}{*}{ Involvements sites of ЕРТВ } & \multirow{2}{*}{$\begin{array}{l}\text { Number of } \\
\text { cases } \\
\text { n }(\%)\end{array}$} & \multirow{2}{*}{$\begin{array}{l}\text { Clinical- } \\
\text { radiological } \\
\text { n (\%) }\end{array}$} & \multicolumn{2}{|c|}{$\begin{array}{c}\text { Microbiological } \\
\text { (culture-ARB) }\end{array}$} & \multirow{2}{*}{$\begin{array}{c}\text { Histopathological } \\
\text { n (\%) }\end{array}$} & \multirow{2}{*}{$\begin{array}{c}\text { PPD } \\
\text { positivity } \\
\text { n (\%) }\end{array}$} & \multirow{2}{*}{$\begin{array}{c}\text { Mortality } \\
\text { rates } \\
\text { n (\%) }\end{array}$} \\
\hline & & & $\begin{array}{c}\text { n (\%) } \\
\text { Culture }\end{array}$ & $\begin{array}{c}\text { n (\%) } \\
\text { ARB }\end{array}$ & & & \\
\hline Lymphadenitis & $54(45.4)$ & - & $6(11.1)$ & $2(3.7)$ & $54(100)$ & $49(90.7)$ & \\
\hline Pleural tuberculosis & $29(24.4)$ & $7(24.1)$ & $10(34.4)$ & $2(6.8)$ & $13(44.8)$ & $25(86.2)$ & \\
\hline Peritonitis & $17(14.3)$ & $4(23.5)$ & $6(35.2)$ & $3(17.6)$ & $10(58.8)$ & $17(100)$ & $1(5.8)$ \\
\hline Bone-Joint tuberculosis & $9(7.5)$ & $5(55.5)$ & $2(22.2)$ & & $4(44.4)$ & $8(88.8)$ & \\
\hline Meningitis & $3(2.5)$ & $2(66.6)$ & $2(66.6)$ & $1(33.3)$ & - & $3(100)$ & $1(33.3)$ \\
\hline Miliary tuberculosis & $2(1.7)$ & $1(50)$ & $1(50)$ & & - & - & $1(50)$ \\
\hline Laryngeal tuberculosis & $2(1.7)$ & - & & $1(50)$ & - & $2(100)$ & $1(50)$ \\
\hline Tuberculosis of GIS & $2(1.7)$ & & - & - & $2(100)$ & $2(100)$ & \\
\hline Tuberculosis of GUS & $1(0.8)$ & - & $1(100)$ & - & - & - & \\
\hline Total & $119(100)$ & $22(18.4)$ & 29 & 4.3) & $83(69.7)$ & $106(89)$ & $4(3.3)$ \\
\hline
\end{tabular}

The histopathological findings were seen to be compatible with TB in 13 of 29 patients with tuberculous pleurisy. In seven cases where tuberculous pleurisy could not be diagnosed histopathologically or microbiologically, and the clinical picture was compatible with $\mathrm{TB}$, the diagnosis was confirmed through the positive response to anti-TB treatment as a result of the presence of exudate pleural fluid and/or the positive tuberculin test under the dominance of lymphocytes.

A quadruple anti-TB treatment was initiated in 110 of the patients with isoniazid $(\mathrm{H})+$ rifampicin $(\mathrm{R})+$ pyrazinamide $(\mathrm{P})+$ ethambutol $(\mathrm{E})$, and the treatment was maintained with the combination of isoniazid + rifampicin (HR). Since the resistance to $\mathrm{H}$ was detected in one pleural TB patient under the treatment, the combination of isoniazid + rifampicin + ethambutol (HRE) was administered as the maintenance therapy, and the treatment period was extended to nine months. In eight patients (seven with recurrent $\mathrm{TB}$, and one case had also abandoned the treatment), with the addition of streptomycin (S) to the classical quadruple treatment, the modality was completed as the combination of isoniazid + rifampicin + ethambutol + pyrazinamide + streptomycin (HERZS) for the first 2 months, as the combination of HRZE for the following one month, and then as HRE for the following 5 months (1). The treatment period of the patients diagnosed with lymphadenitis, pleural TB, and tuberculous peritonitis was completed in six months, while the period of those diagnosed with meningitis and bone-joint TB was completed within 12 months. During the treatment and follow-up period, a total of four cases died, one due to miliary TB, one due to larynx $\mathrm{TB}$, one due to tuberculous meningitis, and the last due to tuberculous peritonitis. While no comorbidity was seen in the cases having miliary TB and TB meningitis with mortal outcomes, malignancy was witnessed in the case with laryngeal TB, and CRF and DM were also seen in the case with tuberculous peritonitis. While the recurrence was observed in one case with peritonitis, two cases (one with pleural TB and the other with bone-joint TB) abandoned the follow-up, and one case with cervical lymphadenitis decided to quit the treatment. While the success rate of the treatment was found to be $93.2 \%$, the mortality rate was measured as $3.3 \%$. A total of 111 cases were cured and/or completed the treatment period.

\section{DISCUSSION}

Keeps on being an important health challenge in developing countries, TB is a disease that can frequently involve other systems, especially the lungs in humans. The clinical signs and symptoms of TB vary according to the involvement site, the load of bacilli, and the host response to TB (4). The patients with TB are admitted to the clinics and out-patient clinics from many different branches depending on the involved organs and systems, and the severity of the disease. For this reason, the awareness of physicians including all branches should be increased about EPTB.

Considering the data related to TB around our country, the rates of EPTB were found to be $55 \%$ in the study performed by Inonu et al. (5), $15.8 \%$ in the study by Oztop et al. (6), 28.1\% in the study of Özdemir (7), and $21.7 \%$ in the study carried out by Demiralay et al (8). Under the data released in 2017 by The Tuberculosis Control Department of The Turkish Ministry of Health, the number of those with extrapulmonary organ involvement was announced as $33.9 \%$.

In the province of Konya, while the total diagnosis of $\mathrm{TB}$ was reported as 236, the number of EPTB diagnoses was stated to be $104(44.1 \%)$ in 2017 (9). The rate of ЕРTB (38.8\%) detected in our study is consistent with the numbers reported for both the province of Konya and the national data. Among the leading predisposing factors in 
the development of infection are immunosuppressive diseases $(6,10)$. It is observed today that the prevalence of EPTB cases is increasing (9). When the presence of comorbid diseases was taken into account in our study, the following comorbid diseases were seen to accompany the patients' tables as DM in eight (6.7\%) patients, malignancy in six (5\%), CRF in eight (6.7\%), and COPD in $5(4.2 \%)$ patients. As a gender difference, EPTB is stated to be seen more commonly in the female gender in the literature $(6,9,11,12)$. As consistent with the findings in the literatüre, $52.9 \%$ of the cases were female, and $47 \%$ were male in our study.

Pleural involvement and lymphadenitis are the most common forms encountered in EPTB. TB bacilli are settled in the nearest lymph node with a hematogenous spread following the primary infection, and so lymphadenitis occurs with the reactivation of these bacilli. In the cases led by TB bacilli, the cervical lymph nodes are the most commonly involved sites (13). Tuberculous lymphadenitis was the most common type of EPTB in our study. As the most common involvement site, cervical lymph nodes $(n=28,51.8 \%)$ were detected in our study, and the cervical lymph nodes were followed by the axillary $(n=23,42.5 \%)$ and mediastinal lymph node $(n=3,5.5 \%)$ involvements, respectively. Based on previous studies, the rates of lymphadenitis were reported as $31.8 \%$ in the study performed by Inonu et al. (5), 53.3\% in the study by Tavusbay et al. (11), and 26\% in the study of Demiralay et al. (8). However, in the study conducted by Aslan et al. (14), lymphadenitis ranked first with a rate of $34.7 \%$ and involved most commonly the cervical region with a rate of $25.7 \%$. In the same study, pleural TB was detected as the second most common type $(18.8 \%)$. The findings in our study are compatible with those reported in the study by Aslan et al. (14) While the rates of lymphadenitis stated by Tavusbay et al. (11) are well-coincided with our findings, the rates detected in Inonu et al. and Demiralay et al.s studies are lower than our findings. The differences in the findings reported by various studies may have also been affected by regional factors, as well as the influences stemming from the physicians' approaches to the follow-up of LAPs. For the cases of pleural TB, the diagnosis is often confirmed with the treatment in case of radiological and clinical compatibility. While the rates of pleural TB were reported to be $47.7 \%$ in the study by Inonu et al. (5), 50.2\% in the study by Kolsuz et al. (15), and $52.8 \%$ in the study by Demiralay et al. (8) we found the rate of pleural TB as $24.3 \%$ in our study. Compared with the findings in those studies, the rate of pleural TB is seen to be lower in our study; the reason for such a difference between the previous studies and our study may be that some pleural TB cases are accompanied by pulmonary $\mathrm{TB}$, and the diagnostic intervention is avoided for pleural TB both because of the predominance of pulmonary TB symptoms, and because pulmonary TB is diagnosed easily. Another reason is that a group of patients give no consent to diagnostic invasive interventions for pleural TB. Because the treatment protocols for the involvements of pleural and pulmonary TB are the same, and the treatment should be initiated without delay in both conditions, it is suggested that the unrecorded cases of pleural TB are treated along with the current cases of pulmonary TB. Considering our findings related to pleural TB, it is seen that $76 \%$ of the cases were diagnosed through the microbiological and/ or histopathological examination of the material (biopsy, pleural fluid) obtained via the invasive intervention, and only $24 \%$ were diagnosed clinically and radiologically. Such a situation suggests that a part of our pleural TB cases accompanying pulmonary TB could not be recorded due to the lack of histopathological and microbiological evidence, whereas these pleural TB cases in our study could have been diagnosed accurately in the light of clinical and radiological findings. Seen between 1 to $5 \%$ of the cases, tuberculous peritonitis is a rare form of EPTB (8). In previous studies, the rates of tuberculous peritonitis were stated as $10 \%$ in the study by Tavusbay et al. (11), as $5.78 \%$ in the study by Sirin et al. (16), and as $3.8 \%$ in the study by Rieder et al. (10). In our study, the rate of cases with tuberculous peritonitis was detected to be higher with a rate of $14.2 \%$. The cases of tuberculous peritonitis detected in our study are generally those examined in the hospitalized patients, with no growth in the cultures and undergoing further investigation due to their unresponsiveness to the combination therapy with various antibiotics. Fourteen of 17 cases with tuberculous peritonitis were diagnosed microbiologically and histopathologically. We consider that such a higher rate of accurate diagnosis was related to the fact that the necessary diagnostic procedures can be performed in our hospital because it is a tertiary research hospital, and the patients referred from the secondary centers were eventually diagnosed in our hospital.

It is difficult to diagnose in EPTB, and so and the first step in the diagnosis process is to always keep in mind the likelihood of EPTB in suspected cases since the clinical symptoms and findings in the patient vary according to the affected organ in EPTB. The diagnosis of pulmonary TB is performed through the direct smear or demonstration of TB bacilli in the culture. Even so, this is not the case in the cases of EPTB, and the situation is slightly different. In diagnosing EPTB, histopathological methods have come to the fore frequently, and invasive interventions are usually required for diagnostic procedures. Therefore, the diagnosis of EPTB is more difficult (12). Of the patients with EPTB, $69.7 \%$ were diagnosed pathologically in our hospital. Such a rate is quite high and shows that the physicians in our hospital have reached a high level 
in diagnostic biopsy procedures. On the other hand, it can also be asserted that the awareness level of the physicians performing biopsies is lower in terms of TB because the material obtained by the surgical branches is usually sent to the laboratory for histopathological examination in 10 percent formaldehyde saline and microbiological examination is neglected. Although the material is sometimes sent to the laboratory for bacterial culture, mycobacterial culture and ARB examination are often overlooked. Considering the increasing anti-TB resistance today, it is obvious that mycobacterial culture plays a role in the regulation of optimal anti-TB therapy. Even in some involvements, mycobacterial culture is of crucial importance.

In the study performed by Inonu et al. (5), the rate of pathological diagnosis was $61 \%$. while the pathological diagnosis was observed to rank first in the diagnosis of EPTB as $69.7 \%$ in our study, the rates of culture positivity, ARB positivity, microbiological diagnosis, and PPD positivity were found to be $23.5,7.5,24.3$, and $89 \%$, respectively. As similar to our findings, while the pathological diagnosis ranked first with the rate of $60.9 \%$ in the study conducted by Kolsuz et al. (15), the rate of culture positivity was found to be quite lower (2.5\%), compared to that in our study. Even so, the rate of PPD positivity was found at a higher rate (95.7\%), similar to our study finding. In the study by Demir et al. (17), ARB positivity was found to be $9.2 \%$. With the samples obtained repeatedly, the demonstrability of the bacilli increases, and so a higher rate of $\mathrm{ARB}$ positivity was achieved as $30 \%$ in the study by Kurt et al. (18). The rates of histopathological diagnoses were found much higher than those of microbiological diagnoses both in our study and in other studies. The alteration in the rates of microbiological diagnosis encountered in various studies is related to the awareness level of physicians about EPTB. Such a situation suggests that the diagnostic biopsy is carried out in terms of the differentiation between malignant and benign samples; infectious factors are sometimes considered by referring bacterial culture to the laboratories, but $\mathrm{TB}$ is not taken into consideration. Therefore we consider that the awareness of EPTB should be increased among all physicians, especially in surgical branches.

While the success rate of the treatment was found as $93.2 \%$, the mortality rate was detected to be $3.3 \%$ in our study. The forms of our EPTB patients resulting in mortality were as follows: one case with miliary $\mathrm{TB}$, one with TB meningitis, one with TB peritonitis, and the last one with larynx TB. The last two cases also had additional comorbidities. The mortality rates were determined as 33.3 and $50 \%$ in TB meningitis and miliary TB cases, respectively. In the study conducted by Aribas et al., the mortality rate among TB meningitis cases was found to be $13.1 \%$ (22). In various previous studies, the mortality rates of TB meningitis cases have been reported between $15-50 \%$ (23). The mortality rate is seen to be between $25-30 \%$ in the cases with miliary TB (24). However, we consider that higher mortality rates of both TB meningitis and miliary TB were associated with the low number of cases in our study since the presence of one case in each form led to higher mortality rates. While the treatment success and mortality rates were found to be 91 and $4.1 \%$ in the study conducted by Gonlugur et al. (19) respectively, the rates of the treatment success and mortality were detected as 91.3 and $2.2 \%$ in the study by Kolsuz et al. (15) respectively. However, in the study by Sengul et al. (20), the treatment success and mortality rates were reported as 94 and $2.4 \%$, and the treatment success was found to be $80 \%$ in the study by Yilmaz et al. (21). The treatment success and mortality rates determined in our study are largely compatible with those found in various studies.

Since our study is of a retrospective design, the fact that no data were available from the patients' files can be seen as a limitation of our study.

\section{CONCLUSION}

Lymphadenitis and pleural TB were determined as the most common involvement form of EPTB in the province of Konya. It should be known that TB is a multisystemic disease and can manifest itself with a wide range of symptoms. In our country where the incidence of TB is encountered at a higher rate, it should also be kept in mind by the physicians in the differential diagnosis that EPTB is difficult to diagnose. If the clinical picture is compatible with EPTB, supportive tests should be performed, the biopsy samples should be obtained from appropriate tissues, and microbiological examinations should be implemented for TB. Finally, if there is sufficient evidence, anti-TB treatment should be commenced immediately.

\section{ETHICAL DECLARATIONS}

Ethics Committee Approval: An approval was obtained from the Medical Specialty Education Board of Konya Training and Research Hospital (Date: 01/08/2019, Desicion No: 28-01).

Informed Consent: Because the study was designed retrospectively, no written informed consent form was obtained from patients.

Referee Evaluation Process: Externally peer-reviewed. Conflict of Interest Statement: All authors also declare no conflict of interest. 
Financial Disclosure: The authors declared that this study has received no financial support.

Author Contributions: All of the authors declare that they have all participated in the design, execution, and analysis of the paper, and that they have approved the final version.

\section{REFERENCES}

1. Tüberküloz Tanı ve Tedavi Rehberi, 2. Baskı Ankara, Mayıs 2019.

2. Aisenberg GM, Jacobson K, Chemaly RF, et al. Extrapulmonary tuberculosis active infection misdiagnosed as cancer. Cancer 2005; 104: 2882-7.

3. World Health Organization (2013) Global Tuberculosis Report 2013. Geneva: World Health Organization. Available: http://apps. who.int. 24 December 2014.

4. Bass JB, Farer LS, Hopewell PC.Diagnostic standards and classification of tuberculosis. Am Rev Respir Dis 1990; 142: 725 35 .

5. İnönü H, Köseoğlu D, Pazarlı C, et al. Bir üniversite hastanesinde takip edilen ekstrapulmoner tüberkülozlu olguların özellikleri. Tur Toraks Der 2010; 11: 167-72.

6. Öztop A, Ünsal İ, Özgü A, et al. Doksanbeş erişkin akciğer dişı tüberküloz olgusu. Solunum Hastalıkları 2004; 15: 34-42.

7. Özdemir M. Retrospective Evaluation of patients applied to tuberculosis dispensary in Osmaniye. TJFMPC 2020; 14; 252-9.

8. Demiralay R. Isparta ili verem savaş dispanserlerinde kayıtlı akciğer dışı organ tüberkülozunun bazı epidemiyolojik özellikleri. Tüberküloz ve Toraks Derg 2003; 51: 33-9.

9. Türkiye’de Verem Savaşı 2017 Raporu, T.C. Sağlık Bakanlığı Verem Savaşı Dairesi Başkanlığı. Ankara 2017. Erişim: https://hsgm saglik.gov.tr/depo/haberler/verem-savas-raporu-2016-2017/ Turkiyede Verem Savasi 2017 Raporu.pdf

10. Rieder HL, Snider DE, Cauthen GM. Extrapulmonary tuberculosis in the United States. Am Rev Respir Dis 1990; 141: 347-51.

11. Tavusbay N, Aksel N, Çakan A, Gülerçe G, Dereli Ş, Özsöz A. Ekstrapulmoner tüberkülozlu olgularımız. Solunum Hastalıkları 2000; 11:294-8

12. Kalaç N, Baflay N, Mutluay Nİ, Bayız H, Özkul M. Ekstrapulmoner tutulum gösteren tüberküloz olguları. Tüberküloz ve Toraks 1999; 47: $213-5$

13. Tatar D, Alptekin S, Coşkunol İ, Aydın M. Lenf bezi tüberkülozlu olguların özellikleri. Solunum Hastalıkları 2007; 18: 20-5.

14. Aslan G, Ülger M, Delialioğlu N, et al. Mersin ilindeki akciğer dışı tüberküloz olgularının mikrobiyolojik ve demografik olarak değerlendirilmesi. Türk Mikrobiyol Cem Derg 2017; 47: 197-204.

15. Kolsuz M, Ersoy S, Demircan N, Metintaş M, Erginel S, Uçgun İ. Eskişehir-Deliklitaş Verem Savaş Dispanseri’nde izlenen akciğer dışı tüberküloz olgularının değerlendirilmesi. Toraks Derg 2003, 4: 25-32.

16. Şirin Y, Coşkunol Ü. Yüz yetmiş üç ekstrapulmoner TB olgusu. Tüberküloz ve Toraks Derg 2002; 50: 272-7.

17.Demir T, Çelik E, Antmen E. Çocuk tüberkülozu olgularının retrospektif olarak incelenmesi. Solunum hastalıkları 1999; 10: 384-91.

18. Kurt A, Poyrazoğlu G, Turgut M, et al. Tüberküloz tanısı ile izlenen hastaların klinik ve laboratuar özellikleri. Fırat Tıp Derg 2006; 11: 55-7.

19. Gönlügür T, Başol G, Gönlügür U, Kütük B. İlimiz dispanserlerinde takip edilen tüberküloz olgularının değerlendirilmesi. İzmir Göğüs Hastanesi Derg 2016; 3: 143-8.
20.Şengül A, Ogan N, Aydemir Y. Akciğer dıșı tüberküloz: Kocaeli Verem Savaş Dispanseri'nde takip edilen 331 olgunun retrospektif incelenmesi. Med J Kocaeli 2015; 4: 4-9.

21. Yılmaz M, Yılmaz A. Düzce Toplum Sağlığı Merkezi Tüberküloz Birimi’ne kayıtlı tüberküloz vakalarının değerlendirilmesi: 20112015. Düzce Tip Fakültesi Derg 2016; 18: 18-22.

22. Arıbaş ET, Yılmaz A, Erayman İ, Bitirgen M. Tüberküloz menenjit: 38 olgunun değerlendirilmesi, Turkiye Klinikleri J Med Sci 1999; 19: 156-60.

23. Doğanay M, Aygen B. Tüberküloz menenjit ve tedavisi. İnfeks Bül 1996;1: 17-20.

24. Matsushima T. Miliary tuberculosis or disseminated tuberculosis. Int Med 2005; 44: 687. 